\title{
Environmental Business as a New Ideologeme of Social Progress: Social and Philosophical Analysis
}

\begin{abstract}
The article presents a social and philosophical analysis of the phenomenon of environmental business as a new ideologeme of social progress. The essence, reasons of occurrence, conditions and directions of the activity of the ecological business in the modern world are analysed. It is concluded that the development of the environmental business is a determinant of the process of the greening of the economy, contributes to the expansion of the environmental thinking of the society and serves as a necessary condition for the sustainable development of the country and the world in general. The environmental business is a vivid example of the interaction between morality and economy.
\end{abstract}

Keywords: environmental business, ecological strategies, greening of economic development, ecological thinking, social progress.

Straipsnyje pateikiama socialinè ir filosofinè aplinkosaugos verslo fenomeno, kaip naujosios socialinès pažangos ideologijos, analizè. Nagrinëjama ekologinio verslo esmé, atsiradimo priežastys, sąlygos ir veiklos kryptys šiuolaikiniame pasaulyje. Daroma išvada, kad aplinkosaugos verslo plètra yra ekologiško ekonomikos proceso veiksnys, prisidedantis prie visuomenès ekologinio mąstymo plètros ir yra būtina sąlyga tvariam šalies ir pasaulio vystymuisi bendrąja prasme. Aplinkosaugos verslas yra ryškus moralès ir ekonomikos sąveikos pavyzdys.

Raktiniai žodžiai: aplinkosaugos verslas, ekologinès strategijos, ekologiškesnis ekonominis vystymasis, ekologinis mąstymas, socialinè pažanga.

"In business, it is important not only to see the future, but to describe it and then bring people to it." (V. Polyakov, an engineer, a multimillionaire)

(The Entrepreneurs about a Business: The Most Striking Quotes of 2011)

\section{Introduction}

The relevance of research. The problem of the environmental business is relatively new to the modern science. It has become relevant since the middle of the twentieth century against the background of the increasing environmental problems that affect almost every country in the world. The emergence of the global problems, including the environmental problem, A. King and B. Schneider (1991) consider 
as the result of the scientific, technical and economic growth of the industrialized countries, the consequence of the unjustifiably high confidence in the technology and the inattention to warnings from philosophers, sociologists and demographers, who anxiously watched the "conversion" of a humanity to the technological believe. They suppose that 1968 was a year of the great turning point, as it marked the end and at the same time the apogee of the long post-war period of the rapid economic growth in the industrialized countries. It was at that time when the anxiety aroused of the global community about the environment. The same opinion is followed by V. L. Inozemtsev (2003), rightly noting that the second half of the twentieth century was marked by peace and prosperity for the Western countries. But unfortunately, it did not bring any good to the population of other regions of the planet and was a period during which, for the first time in history, the environmental problems became no less actual and dangerous than political and economic ones. Therefore, the direct participation in the environmental solution is a matter of honor and a public responsibility of business as an important public institute.

\section{The level of problem exploration.} For the most part, the study of the environmental business is conducted in terms of the economic science. For example, L. G. Melnyk, S. D. Kalashnyk and V. V. Sabadash (2001) analyse the relationship between economic growth strategy and environmental security. V. Yatskov (1994), L. G. Melnyk and S. O. Skokov (2001) analyse the resource conservation as a direction of the nature management; V. I. Krutyakova (2001) examines the market mechanisms of the development of the environmental entrepreneurship in Ukraine; E. Boon (2001) analyses the system of environmental management at the enterprise, S. Mikhnevich (2004) examines the questions of the liberalization of the agricultural trade in a relation to the competition policy. P. H. Zeidfoodym and N. F. Gazizullyn (1992) analyses in detail the social and environmental motivation of the entrepreneurial activity. The instruments of the greening of the development of the economic system are investigated by S. N. Bobylev (1993), V. N. Boronos and I. D. Sklyar (2001), V. I. Kononenko, O. O. Veklych, L. M. Shablysta and others (2002). The questions of consumerism in the context of expanding environmental consciousness are in the spotlight of Z. Musová, H. Musa and L. Ludhova (2018), K. Bhattarai (2019). V. Tregobchuk, O. Veklych (1997), S. Ilyashenko, G. Lander, V. Melnyk (1998) and V. Koziuk, O. Dluhopolskyi, A. Farion and others (2018) analyze the possibilities of the creation of the Ukrainian ecological market. Issues related to the development of ecological tourism are explored by V. V. Yavorska, I. V. Hevko, V. A. Sych and others (2018), S. Kaygili, D. Sinanoglu, E. Aksoy and others (2018), N. Ye. Pankiv, O. R. Roik (2019). The problems of the ecological culture are at the centre of the attention of A. M. Kochergyn (2015), A. N. Pavlova (2004), L. V. Sennitskaya (2015). The questions of the social ecology and the environmental ethics that are relevant to the entrepreneurial activity are highlighted in their works by M. A. Golubets (1997), A. Yu. Zhulavsky (2001), S. A. Mikhayluk (2006), O. Yu. Kolosova (2008), I. A. Ilinykh (2009), T. M. Pavlova (1997), I. K. Liseyev (2009), M. M. Rogozha 
(2015), D. J. Markovych, V. I. Zhukov and V. R. Bhanba-Cerera (1998), G. O. Bilyavsky, L. I. Butchenko and V. M. Navrotsky (2002), V. S. Krisachenko, S. V. Crimsky and M. A. Golubets (1991), L. Mitych (2015), B. J. Callicot $(1984,1990,1999)$, E. Deutsch (1970), N. Roderick (1989), D. Birnbacher (1982), R. Atfield (1990), L. White (1990) and others. The anxiety about the ecological future of humanity is palpable in works by T. Yu. Sidoryna (2003), A. D. Ursul (1990), S. Sonco, Yu. Kiseliov, S. Polovka (2018), A. King and B. Schneider (1991). The comprehension of the crisis phenomena in the natural environment and the ways to overcome them, the analysis of the international conventions on the environmental protection that are adopted in the second half of the twentieth century, find a place in the scientific work by V. L. Inozemtsev (2003).

The object of research: the phenomenon of the environmental business from a social and philosophical point of view.

The aim of research. Based on the analysis of the theoretical studies in domestic and foreign scientific literature, to make a social and philosophical analysis of the essence of the environmental business and to prove that it is a new ideologeme of social progress.

\section{The objectives of research:}

1. To analyse the essence of the environmental business from a philosophical standpoint.

2. To investigate the conditions for the successful development of the ecological business in the modern world.

3. To find out the strategically important directions of the activity of the business in the nature protection area (environmental business).
4. To prove that the environmental business is a strategically important direction of the development of the world economy and the economy of Ukraine, in particular.

5. To prove through the prism of the social and philosophical analysis that the environmental business can be rightly interpreted as the new ideologeme of the social progress.

6. To prove that the development of the ecological business is a manifestation of the relationship between morality and economy in the modern world.

The methods of research. The realization of the goal of the research and the need to solve the set tasks led to a methodological synthesis of integrative and interdisciplinary approaches in the process of analysing of the environmental business as a complicated social phenomenon.

The theoretical basis of the study was the general scientific principles of the system-structural and structural-functional analysis in combination with the method of deconstruction. This allowed us to trace the reasons for nascence and the directions of environmental business and to thoroughly analyse the "pain points" in the question of conditions for its successful development in the modern world.

The dialectical method was used to analyse, firstly, the genesis of the subject of study; secondly, the contradictory interrelation of various factors of its successful development (economic instruments (financial market, credit, etc.) and the voluntary activity of business people and the command and controlling functions of the legislation in order to successful development of the ecological entrepreneurship). The analysis of the abovementioned factors for the effective development of 
ecological business was carried out on the basis of the complementarity method.

The principles of synergetics have made it possible to consider the environmental business as an open self-developing system and the formation of which becomes possible at the level of interaction of the various factors in a global world.

The method of synthesis of the information from domestic and foreign scientific literature, comparative method, analogy, historical method, and logical method were also used.

The social and philosophical analysis of the environmental business as a new ideologeme of social progress was carried out within the complementary application of the abovementioned methods.

\section{The reasons of the occurrence and the directions of the activities of the environmental business}

The implementation of the governments' environmental policies has led to the development in Western Europe of a new manufacturing industry. It is the ecological industry, which provides for the development and marketing of the equipment for the control and the prevention of pollution, as well as environmental researches, ecological monitoring and environmental consulting services (Krutyakova, 2001).

The growth rate of the ecological business is considerable. Analysis of the global environmental market shows that in the foreign trade volume of the developed countries, the share of the environmental sector is up to $5 \%$, with the growth rate of the sales of the environmental technologies and equipment reaching $10 \%$ per year. The global environmental market is estimated at \$ 260 billion, with sales of \$ 570 billion expected by 2010 . The ecological market is growing fast approximately $5 \%$ per year. At that the average annual growth rate of the global ecological business in its priority areas being $8.5 \%$ with the growth of the single segments of the ecological market (for example, the land restoration equipment) to $16.1 \%$. The USA is the world market leader: they account for more than $1 / 3$ of total sales. Their serious competitors are Germany, Japan, France, and the United Kingdom (Tregobchuk, Veklych, 1997; Ilyashenko, Lander, Melnyk, 1998).

According to some reports, the gross additional product produced in the EU ecological industry in 1994 was $\$ 41.7$ billion, representing $0.5 \%$ of GDP in these countries. It is expected that the real growth of the environmental sector in the next 5-10 years will exceed the similar indicator for the economy as a whole. This will be thanks to the accession of new members to the EU. As a consequence, the role and the importance of the environmental businesses in these countries will increase considerably (Krutyakova, 2001).

Since now in most countries of the world, the institute of the state has rather limited resources to solve the environmental problems, the initiative must come from the private sector (entrepreneurship).

The strategically important areas of the activity of the business in the environmental sphere (environmental business):

- the production of the environmentally safe means of the alternative energy (solar panels, windmills, equipment that transforms the power of the sea waves into energy, and others); 
- the development of geothermal energy. It is the direction of the energy based on the production of the electric and heat energy due to the heat energy contained in the earth's interior and at the geothermal stations (The Increasing Energy Efficiency and the Stimulating the Use of Renewable Energy in Agricultural and Food and Other Small and Medium Enterprises (SMEs) of Ukraine.)

In 2004, the total summary of the geothermal power plants in the world was about 9 million $\mathrm{kW}$ and the geothermal heating systems - about 20 million $\mathrm{kW}$ (heat). According to forecasts, the power of the geoTPPs can be about 20 million $\mathrm{kW}$. The electricity generation can be 120 billion $\mathrm{kWh}$. In Iceland, for example, due to geothermal energy is generated $26.5 \%$ of all electricity produced (The Energy. History, Present and Future);

- the application of the environmental production methods, the implementation of the measures to overcome the environmental pollution as a result of production;

- the implementation of the practice of resource conservation as one of the leading areas of the environmental policy of the modern entrepreneurship.

First of all, this practice involves the organization of enterprises that will sort and recycle the garbage in order to reuse the resources of plastic, glass, paper, etc. For example, the modern technologies already allow for the use of recycled plastic in road construction and shoe industry.

In addition, it is well-known that the resource conservation plays a considerable role in the reducing of the material consumption of social production. How- ever, in order to achieve the resource conservation considerable work is needed:

- at the level of the enterprises and organizations: development, implementation, large-scale production and the use of resource-saving and high-tech types of the technologies, materials, and methods of the management;

- at the level of the branches, national economic complexes, the economy of the country as a whole: the purposeful and balanced investment, tax and scientific and technical policy (Melnyk, Skokov, 2001). In the modern world, large industrial companies are more and more refusing to use the rare materials that are related to large-scale interference with the nature. So, the creation by the "Kodak" of the silver-free method of the photographing has sharply reduced the market for this metal; the same thing happened when the "Ford" announced the introduction of the catalysts based on platinum substitute. Then the chip makers refused to use the gold contacts and conductors. So, the developed countries in a natural way, without any international agreements and conventions, limit the inefficient use of natural resources and reduce the burden on the environment (Inozemtsev, 2003).

- the intensification of the cooperation with the developers of the innovative scientific and technical products, which will allow in practice to apply the resource-saving technologies, ecological types of raw, materials and fuels, environmental protection equipment.

Such interaction can also entail the long-term private sector investment in the research projects designed to find ways of the overcoming environmental problems. An important factor in the formation of 
an ecological economic system is not so much the restriction of the use of a certain factor of the production or the prohibition of the atmospheric pollution, but the creation and use of the new technologies; they are capable of the shaping an economy that will no longer threaten the very existence of the biosphere (Inozemtsev, 2003).

- initiating and conducting environmental actions, such as environmental monitoring.

For example, the air pollution control stations operated by the private sector are located in the major cities in the Philippines. The screens are installed in public places to show the state of the atmosphere, which promotes the public awareness. By the operating advertisements around the information screens, the operating private company compensates for its losses:

- the organization of the public relations, including, in particular, the patronage by the private companies of the urban water supply, the heating, the collection and the disposal of the waste and green space;

- the organization of the charitable activities in order to the overcome of the urgent problems in the environmental sphere;

- the greening of the enterprise's relations with the consumers of the products, which envisages, on the one hand, the promotion of the supply for the environmental commodities and services; on the other hand, the formation of the consumers, so to speak, a good "taste" namely the economic needs and interests, focused on the high environmental standards.

So, in Western Europe, the demand for organic products is growing rapidly: vegetables, fruits, wines, etc. As a conse- quence, the development of the agricultural ecological businesses (for example, the livestock and the growing crops in the accordance with accepted ecological standards), the winemaking focused on the production of the environmental food:

- the use of the livestock products in order to produce a methane as an alternative energy source;

- the production of the safe and environmental building materials (the processing of the wood waste into the pellets and brackets, the production of the wall heaters of the houses from the straw);

- the construction of the housing stock from the ecological materials: wood, stone, straw, clay, etc. Such, relatively cheap, the type of construction is particularly in demand in the countries with low levels of economic development;

- the participation in the formation of an active environmental "lobby" in the state bodies, which will be expressed in the initiation and acceptance of the relevant legislative acts, laws, etc., whose implementation in practice will, at least, in part, to solve the existing environmental problems and to prevent the emergence of new ones; in the creation of the new environmental programs and their financing both by the state and the entrepreneurship;

- the active development of the ecological tourism. It is a type of tourism that is connected with the knowledge of nature and is aimed at preserving ecological systems while respecting the interests of the local population (Dmytruk, 2004). 
The above-mentioned directions of the activity of the ecological entrepreneurship are extremely relevant for modern Ukraine.

Ukraine, like never before, needs the systematic environmental steps from a state and a business. It is well known that the potentially environmentally dangerous industries have had and have a large share in the structure of industrial production in Ukraine. In the early 2000s, experts evaluated that in the country, environmentally dangerous industries were for almost half of the value of the fixed assets, more than $60 \%$ of the production (Galchinsky, 2000). Today, this figure is much higher.

The conducting recreational policies in the western regions of Ukraine is becoming particularly relevant because there is a massive deforestation and amber production that is not authorized by a state. There are reasons to believe that the structure of the Ukrainian economy is environmentally deformed. (Kononenko, Veklych, Shablysta et al., 2002). So, a business must be shaped by a clearly ecological strategy, with the support of the state. Its main purpose is to protect and to prevent environmental pollution. This will create preconditions for the sustainable social and economic development of the country (Boon, 2001). It should be noted that in the_1999/2000 World Development Report, sustainable development is treated as a way of being of the modern world that envisions the equality between generations, that is, enabling future generations to evolve in the same way as the present generation develops. The way of the development becomes sustainable only if it ensures the preservation and the growth of the total capital assets over time (the processed capital (machines, mecha- nisms, roads), the human capital (knowledges, skills), the social capital (relationships and institutions) and the ecological capital (forests and coral reefs) (1999/2000 World Development Report, 2000).

The sector of the national ecological market has not been formed yet in Ukraine despite the objective necessity of the ecological transformation of the domestic technological production method and the numerous potential economic, ecological and social benefits that can ensure the development of the ecological industry. (Although the analysis of the current processes gives an opportunity to see already the sufficiently stable sprouts of the new industry for the production of commodity and services of the environmental purpose that is the ecological industry). It is noteworthy that Ukraine is considered as an attractive investment region of a possible dynamic market for environmental protection products and services, according to the foreign experts (Kononenko et al., 2002). This estimation is concretized by data from the national market researches on the potential and real environmental equipment manufacturers and environmental service providers. So, $77-85 \%$ of the enterprises in Ukraine can engage in the development/ production of the drinking and rainwater treatment equipment; $85-91 \%$ can be engaged in treatment plants of the industrial and agricultural waters; $61-69 \%$ of the enterprises can develop/produce the equipment for the purification of the compounds of nitrogen and metals, mineral, chemical fertilizers and herbicides, $69-77 \%$ - for the purification of phenols and oxidizable organic substances, $77-85 \%$ - for the disposal of heavy metal compounds and mechanical impurities, $91-96 \%$ - for refining of 
petroleum products and waste from their processing (Sosurko, Zhuykov, Zolotareva, Petergerya, 2000). Today, based on a high scientific potential, first of all, on the technical capabilities of the militaryindustrial complex, the environmentally oriented entrepreneurial activity forms on the basis of the machine-building industry in Ukraine. According to experts, the average annual growth of the ecological market in the countries of Eastern Europe (in particular, the CIS) is estimated at $1.2 \%$ ( $\$ 1.1$ billion). From here we can assume that a similar situation is true for Ukraine (Ilyashenko, Lander, Melnyk, 1998).

\section{The conditions for the successful development of the environmental business}

Any organization or enterprise needs the development of a clear and detailed environmental strategy. In the modern world, the private sector and businesses increasingly involved in the financing of the infrastructure development projects and providing environmental services (Krutyakova, 2001). However, the private sector participates in financing such projects only when they securely generate profits. So, first of all, it is necessary to create the favourable conditions for participation of the private sector in the environmental projects through the reform of the tariffs and formation of the legislative field to protect the interests of the internal and external investors.

In this case, the state must have a clear and undeniable imperative of the private property. Axiomatic is the thesis that the security of property rights is a necessary prerequisite for attracting investment in the sectors that ensure the health of the public and the environment. No one is fully responsible for the ecological system degradation in the countries where access to the natural resources is fully open. As a consequence, overuse of natural resources. But if there is an orderly system of property rights instead of open access, the likelihood that a person (a group of the owners) will be responsible for the environmental degradation and benefit from the protection of nature is the sharply increased. The property rights are an important means by which the conservation of the natural resources can be ensured (Romanchuk, Y.).

For the successful development of environmental entrepreneurship, it is also necessary to create a financial foundation that would allow the implementation of the medium and long-term projects for infrastructure development and industrial modernization. After all, it is possible to save and release from the reproduction cycle $20-30 \%$ of the natural resources with the growth of the final product owing to the ecological modernization of the technological base of the production (Bobylev, 1993). It is important commercial banks can expand their possibilities to lend the environmental programs and to take into account the needs of the environment in their core business. This may be facilitated by foreign assistance in the form of technical assistance, the provision of the long-term credit facilities and the development of the specific facilities, such as mutually beneficial investments aimed at energy conservation and the use of clean technologies. In addition, it is necessary to consider the possibility of using guarantees of international financial organizations to 
improve the conditions of internal lending (Krutyakova, 2001).

At the same time, the promotion of environmental entrepreneurship can really be achieved only by providing the certain benefits to the producers and consumers of the environmental products. An extensive system of economic instruments can form the motivational basis for the development of environmental entrepreneurship. It is based on a balanced combination of the regulators of the coercive and restrictive nature with the regulators of the incentive and compensation nature, as is known from the experience of environmental management in other countries. In this way, it is possible to create more favourable conditions for both environmental and resource conservation, and for the introduction of the environmental technologies and methods of the management, for the formation of the ecological industry as a promising industry. So, to achieve the ecological structural changes in the structural policy. How foreign experience convinces, the selective and well-thought-out practice of the using economic instruments of the rationalization of the environmental management creates the opportunity to reach a higher quality, more efficient and environmental level of the production, while reducing public environmental costs. It is known that the task of the environmental policy is to protect the environment by creating more environmental and less resource-intensive technologies, the restructuring of the industrial production in an innovative environmental type, the implementation such management methods that simultaneously increase its efficiency and reduce the pollution, as well as create the environmental orientation at buyers (Kononenko, 2002).

So, it is necessary to combine the economic instruments (financial market, credit, etc.) and the voluntary activity of business people and the command and control functions of the legislation in order to successful development of the ecological entrepreneurship (Krutyakova, 2001).

As an important factor in the development of the ecological business is also the activation of the environmental awareness of the society, the awareness at the level of the public and the individual that the economic and environmental spheres of the public life are closely interconnected. The state of the natural environment affects economic activity, determines the nature of the economic processes; at the same time, the economic decisions have a considerable impact on the environmental condition.

It becomes possible to overcome the traditional dilemma: "environment or economy" and the transition to opportunity to make the choice: "environment and economy" with the introduction of an active state environmental policy (Krutyakova, 2001). A consonant point of view is expressed by the famous American scientist M. Porter (2000). He argues that humanity will enter the 21 st century with a new paradigm. The successful companies disagree with the outdated approach "or-or" and build their business on the basis of the economic logic that establishes a clear relationship between the environment, resource productivity, innovation and competitiveness. The senior leaders, educated at a time when environmental legislation has been associated with endless litigation, 
are increasingly seeing how environmental protection become truly profitable business. V. L. Inozemtsev (2003) considers the problem from the same angle of view. He notes that an ecology today is not opposed to the economy; the improvement of the situation in the sphere of environmental protection is possible only if it is considered as a problem. Meanwhile, the main subjects of economic life today are large corporations and companies, operating in the "third" world. They depend much more than the governments of the great states. It is necessary to create a system of economic preferences and sanctions in order to achieve real results. They will be applied to the companies and countries that seek or impede environmental programs. Applying sanctions against Brazil until the deforestation of the Amazon is stopped, or the most product-friendly mode for a company has become a technology leader that can sharply reduce fuel use, is more effective event than the calling for entire countries to reduce the emissions of harmful gases into the atmosphere. The countries do not emit waste. They are thrown away by the people and industrial companies, and without shifting the main focus to this level, success in the large-scale environmental activities is impossible (Inozemtsev, 2003).

So, the statement of the unity of the development of economy and ecology, of the interdependence of the economic phenomena (processes) and the state of the environment is a new paradigm of the social development. The awareness that it is impossible to build a stable and "healthy" economy at the expense of the environmental damage, that it is necessary to develop the economy with tak- ing into account the needs of the environment, has become a significant step towards the creation and development of the ecological industry. So, the environmental determinant, becoming more and more sensitive in the system of the economy, determines the prospects for its further development. It should be enhanced by the active participation of the entrepreneurship in the environmental protection activities. The environmental business is emerging as a new ideologeme of the social progress.

The interest of the economic entities in the implementation of the lowwaste and resource-saving technologies, in the production of the environmental ("green") products, the spread of the environmental management should be constantly stimulated. It is about implanting environmental goals into the interests of the national producers. This is another important condition for the successful development of an ecological business. Therefore, it is imperative to introduce an effective, coherent state incentive and enforcement system of administrative, legislative, market and economic instruments of the environmental regulation, which will help align the interests in the production of end products with the environmental goals. (Kononenko et al., 2002). These include, in particular, reducing the tax burden on the ecological industry enterprises, their preferential lending, a system of the incentives for consumers of the environmental products, etc.

The analysis of the modern foreign economic practice shows that environmental protection is considered as an important economic task of the enterprise. The nature conservation activities contribute 
to the prosperity of a business and give a positive result for the economy as a whole. The economy is gaining a solid resource base for its own development, relying on waste-free and environmental technologies (Kononenko et al., 2002).

The development of the industry for the protection and the reproduction of the natural environment, the market of products and services of the ecological purpose, is an important direction of the greening of social production. Judging by the experience of other countries, it is cost-effective and promising. It is important that the development of ecological entrepreneurship, which uses mainly the powers of small and medium-sized businesses, is an effective way to the stabilization of ecological and economic situation without requiring additional budgetary allocations. The idea of sustainable development is impossible for the national economies of the developed countries to implement without an ecological industrialization. It contributes to solving current ecological and economic problems and eliminates the negative technogenic burden on the environment. At the same time, the ecological industrialization of the national economies also forms a promising and highly effective source of the growth of the aggregate social product, strengthens domestic competitiveness and activates international trade and stimulates the ecologically positive shifts in the system of the international division of labour and international relations. (Kononenko et al., 2002).

It should be noted that the environmental determinant, acting as an equal element of the national economic system, plays a key role in the formation of the environmental security system, which, in turn, becomes an integral part of the national security system (Melnyk, Sabadash, Kalashnyk, 2001). So, the environmental business can be an effective tool for managing the country's sustainable social and economic development in the context of the country's economic security, because it contributes to the greening of the human and social life and to the overcoming environmental problems.

\section{Conclusions}

So, the formation of a foundation for creation and development of environmental business becomes possible with the awareness of the urgent need to address the issue of the environmental protection, which acquires with the development of modern civilization on a global scale, with the development of the environmental awareness at the level of the individual and society, with the expansion of the private sector in the economy and the delegation to it by the governments of clear rights and powers in the field of environmental policy.

The ecological business, which is a manifestation of a high level of economic activity, has a positive influence on the formation of a new environmental concept. It is adequate to the needs of the new century. The environmental business contributes to the greening of the economic development, acting as a guarantor of the country's sustainable development.

The success of an entrepreneur and a powerful corporation is known to be determined by many factors and, in particular, the interconnection of the type: "entrepreneur - society", in other words, the extent of the entrepreneur's responsibility 
to the society and public. Therefore, the entrepreneurial activity should be organized and carried out taking into account not only the private economic interests but also the interests and needs of society, its consequences should be positive for it. That is, it must be socially oriented.

So, the environmental business is the optimal form of the development of modern entrepreneurship as an area of the activity of socially oriented entrepreneurship. It meets the requirements of today: firstly, by helping to solve environmental problems; secondly, by revolutionizing established (traditional) forms of the business development, in line with the latest environmental thinking; thirdly, acting as a factor in the development of an ecologically oriented economy, both separate and global.

The development of environmental entrepreneurship is an important component of the state's environmental policy, a precondition for building an environmentally safe world. Therefore, promoting ecological business is becoming an important component of the policy, not only within the separate country but the world at large. At the same time, it should be noted that the development of the environmental business requires coordinated actions by the state, private sector, members of the public and international institutions.

Practically, all the above-mentioned directions of the activity of the ecological business are acceptable for the development in Ukraine.

The environmental business requires a qualitatively new level of self-awareness of the population for its successful progress as a condition for achieving a higher level of economic development, which is characterized by more environmental technologies.

The ecological business as a form of the entrepreneurial activity, focused on satisfying not only private but also public economic interests and on the needs of society, is a clear manifestation of the impact of morality on the economy, its ability to influence and determine the economic existence of human. So, the environmental business is a promising direction of activity of the socially oriented entrepreneurship, both from the standpoint of a commercial calculation and from the standpoint of a morality.

The environmental business is a promising direction of entrepreneurship both from the technocratic point of view, namely from the point of view of its efficiency, profitability and from the point of view of the influence on the humanistic perfection of a person. After all, the ecological business creates the means and conditions for improving the conditions of a human activity, the development of creative human potential. Therefore, it is a new ideologeme of the social progress. 


\section{References}

1. 1999/2000 World Development Report. (2000). On the Threshold of the 21st Century. - M.: All World Publishing House, World Bank.

2. Atfield, R. (1990). The Ethics of Environmental Responsibility // The Global Problems and Universal Values. - M.: Progress, pp. 203-257.

3. Bhattarai, K. (2019). Consumers' Willingness to Pay for Organic Vegetables: Empirical Evidence from Nepal // Economics and Sociology. Vol. 12, No. 3, pp. 132-146. doi: 10.14254 / 2071789X. 2019 / 12-3 / 9

4. Bilyavsky, G. A., Butchenko, L. I., Navrotsky, V. M. (2002). The Ecology Assessments: Theory and Workshop: A Tutorial. - K.: Libra.

5. Birnbacher, D. (1982). A Priority Rule for Environmental Ethics // Environmental Ethics. Vol. 4.

6. Bobylev, S. N. (1993). The Greening of the Economic Development: A Tutorial. - Moscow: MSU, p. 33

7. Boon, E. (2001). Creating Environmental Management Systems // The Mechanism of the Regulation of Economy, the Economy of Nature Management, the Economy of Enterprise and the Organization of Production. No. 1-2, pp. 25-37.

8. Boronos, V. N., Sklyar, I. D. (2001). The Cyclicity of the Development of Economic System and the Tools of Ecologization of the LongTerm Development // The Mechanism of the Regulation of Economy, the Economy of Nature Management, the Economy of Enterprise and the Organization of Production. No. 1-2, pp. 54-56.

9. Callicot, B. J. (1984). Non-Anthropocentric Value Theory and Environmental Ethics / B. J. Callicot // American Philosophica Quarterly. No. 21. p. 299.

10. Callicott, B. (1990). The Asian Tradition and the prospects for Environmental Ethics: The Propedeutics // The global problems and the human values. - M.: Progress, pp. 308-327.

11. Callicott, B. (1999). The Environmental Values and Ethics // The Humanitarian Ecological Journal. No. 1(2), pp. 40-67.

12. Deutsch, E. (1970). Vedanta and Ecology // Indian Philosophical Annual. Vol. 7, pp. 79-88.

13. Dmytruk, O. Yu. (2004). The Ecological Tourism: The Modern Management and Marketing Concepts: A Tutorial. - K.: Alterpres. p. 192 Internet access: <http://tourlib.net/books_green/ dmytruk1.htm>, [accessed August 20, 2019].
14. Galchinsky, A. (2000). To Restore the Capacity of the State // The Economy of Ukraine. No. 8, p. 8.

15. Golubets, M. A. (1997). From the Biosphere to the Sociosphere. - Lviv: Polly.

16. Ilinykh, I. A. (2009). The Environmental Ethics: A Tutorial. - Gorno-Altaisk: RIO GAGU.

17. Ilyashenko, S., Lander, G., Melnyk, V. (1998). The Research of the Ecological Markets in Ukraine // The Economics of Nature Management. - K.: Naukova dumka.

18. Inozemtsev, V. L. (2003). The Environmental Issues and the Economic Feasibility. The Crisis of the Kyoto Agreements and the Problem of the Global Climate Warming // At the Turn of the Epochs. The Economic Tendencies and their Non-Economic Consequences / Inozemtsev, V. L. - M.: "Ekonomyka" Publishing House, pp. 491-492.

19. Kaygili, S., Sinanoglu, D., Aksoy, E., Sasmaz, A. (2018). Geoturism: Some Examples from Turkey // Journal of Geology, Geography and Geoecology. Vol. 26, No. 1, pp. 79-87. doi: https://doi.org/10.15421/111809

20. King, A., Schneider, B. (1991). The First Global Revolution. - M.: Progress: "Progress - Panagya”.

21. Kochergyn, A. N. (2015). The Ecological Culture as a Factor of the "sustainable development" of a Society: Problems, opportunities, Realities // The Forest Herald. - Mytishchi: MGUL Publishing House. No. 4, pp. 33-36.

22. Kolosova, O. Yu. (2008). The Ecological Imperative as a Social and Cultural Phenomenon // The Humanities and Social and Economic sciences. No. 2, pp. 39-43.

23. Kononenko, V. I., Veklych, O. O., Shablysta, L. M., et al. (2002). The Mechanism of the Structural Shifts in the Economy of Ukraine. K.: Inst. of Economics of NASU.

24. Koziuk, V., Dluhopolskyi, O., Farion, A., Dluhopolska, T. (2018). Crony Sectors as a Barrier to Economic Well-Being and Ecologization (Case of Ukraine) // Economics and Sociology. Vol. 11, No. 3, pp. 113-132. doi: 10.14254 / 2071-789X. 2018 / 11-3 / 7

25. Krutyakova, V. I. (2001). The Market Mechanisms of the Development of Ecological Entrepreneurship in Ukraine // The Ecological Innovations. No. 12, pp. 240-245. 
26. Krysachenko, V. S., Krimsky, S. V., Golubets, M. A., et. al. (1991). The Ecology and the Culture. - K.: Naukova dumka.

27. Liseyev, I. K. (2009). The Ecological Ethics in the Conditions of New Ecological Culture // The Philosophy and the Ethics: A Collection of the Scientific Works. - M.: Alpha-M, pp. 723-736.

28. Markovych, D. J., Zhukov, V. I., Bhanba-Cerera, V. R. (1998). The Social Ecology: A Tutorial. M.: Publishing house of MGSU "Soyuz".

29. Melnyk, L. G., Sabadash, V. V., Kalashnyk, S. D. (2001). The Strategy of Economic Growth and the Problem of Environmental Safety // The Mechanism of the Regulation of Economy, the Economy of Nature Management, the Economy of Enterprise and the Organization of Production. No. 1-2, pp. 25-37.

30. Melnyk, L. G., Skokov, S. A. (2001). The Resource Conservation as a Direction of Nature Management // The Mechanism of the Regulation of Economy, the Economy of Nature Management, the Economy of Enterprise and the Organization of Production. No. 1-2, pp. 70-73.

31. Mikhailuk, S. A. (2006). The Theoretical Origins of the Environmental Ethics // The Current Philosophical and Cultural Problems of the Present: A Collection of Scientific Works. Issue 17. Pp. 176-183.

32. Mikhnevych, S. (2004). The Liberalization of the Trade in Agricultural Products and the Competition Policy // The Society and the Economics. No. 5-6, pp. 215-224.

33. Mitych, L. (2015). The Ecological Upbringing and the Education in the Function of Nature Protection // The Forest Herald. No. 4, pp. 43-48.

34. Musová, Z., Musa, H., Ludhova, L. (2018). Environmentally Responsible Purchasing in Slovakia // Economics and Sociology. Vol. 11, No. 4, pp. 289-305. doi: 10.14254 / 2071789X. 2018 / 11-4 / 19

35. Pankiv, N. Ye., Roik, O. R. (2019). Green Ways as a Form of Sustainable Tourism Development in Lviv Region (on the Example of Yavoriv District) // Journal of Geology, Geography and Geoecology. Vol.28, No 1, pp. 159-172. doi: https: $10.15421 / 111917$

36. Pavlov, A. N. (2004). The Basics of Environmental Culture. - St. Petersburg: Polytechnic.

37. Pavlova, T. N. (1997). The Bioethics in the High School. - M.: MGAVMB by K.I. Skryabyn.
38. Porter, M. E. (2000). The Competition: Trans. with English: Uch. pos. - M.: Ed. Williams House.

39. Roderick, N. (1989). The Rights of Nature. - The University of Wisconsin Press.

40. Rogozha, M. M. (2015). The Ecological Ethics in Civil Society: The Theoretical and Applied Aspects // The Forest Herald. - Mytishchi: MGUL Publishing House. No. 4, pp. 64-69.

41. Romanchuk, Y. The Myths and the Facts about the Concept of Monopoly. Internet access: <http://www.research.by/webroot/delivery/ files/ecowest/1999n4r09.pdf> [accessed August 25, 2019].

42. Sennitskaya, L. V. (2015). The Role of the Education in the Formation of the Ecological Culture // The Forest Herald. No. 4, pp. 70-74.

43. Sidoryna, T. Yu. (2003). The Crisis Philosophy: A Tutorial / T. Yu. Sidoryna. - M.: Flint: Science.

44. Sonco, S., Kiseliov, Yu., Polovka, S. (2018). About the Modern Concept of Environment // Journal of Geology, Geography and Geoecology. Vol. 27, No. 2, pp. 346-356. doi: https://doi. org/10.15421/111859

45. Sosurko, Yu. V., Zhuykov, V. Ya., Zolotaryova, L. S., Petergerya, Yu. S. (2000). The Preparation and the Conducting of the Leasing Operations in the Sphere of Ecology. The Practical recommendations. - K.: Avers.

46. The Energy. History, Present and Future. Internet access: http://energetika.in.ua/en/ books/book-5/part-1/section-2/2-8> [accessed August 7, 2019].

47. The Entrepreneurs about a Business: The Most Striking Quotes of 2011. Internet access: <https://www.forbes.ru/svoi-biznesopinion/predprinimateli/itogi-2011/77941predprinimateli-o-biznese-samye-yarkie-tsitaty $>$ [accessed August 7, 2019].

48. The Increasing Energy Efficiency and the Stimulating the Use of Renewable Energy in Agricultural and Food and Other Small and Medium Enterprises (SMEs) of Ukraine. Internet access: <http://www.reee.org.ua/ renewable-energy/heothermal-enerhetics/> [accessed August 7, 2019].

49. Tregobchuk, V., Veklych, O. (1997). The Need for an Ecological and Economic Model of Market Reforms in Ukraine // Economy of Ukraine. No. 4, p. 22.

50. Ursul, A. D. (1990). The Prospects of the Environmental Development. - M.: Science. 
51. White, L., Jr. (1990). Historical Roots of our Ecological Crisis // Global Problems and Universal Values. - M.: Progress, pp. 188-202.

52. Yatskov, V. (1994). The Problems of the Resource Saving // Economy of Ukraine. No. 3, p. 46.

53. Yavorska, V. V., Hevko, I. V., Sych, V. A., Kolomiyets, K. V. (2018). The Main Components of the Formation of Recreational and Tourism Activity // Journal of Geology, Geography and Geoecology. Vol. 27, No. 1, pp. 148-155. doi: $10.15421 / 111840$

54. Zeidfoodym, P. H., Gazizullyn, N. F. (1992). The Social and Ecological Motivation of the
Entrepreneurial Activity // The Sociological Research. No. 9, pp. 65-70.

55. Zhulavsky, A. Yu. (2001). The Ecologization of the External Environment of the Enterprise // The Mechanism of the Regulation of Economy, the Economy of Nature Management, the Economy of Enterprise and the Organization of Production. No. 1-2, pp. 38-49.

The paper submitted: September 27, 2019 Prepared for publication: December 10, 2019

Liudmyla SEVERYN-MRACHKOVSKA

\section{APLINKOSAUGOS VERSLAS KAIP NAUJA SOCIALINĖS PAŽANGOS IDEOLOGIJA: SOCIALINĖ IR FILOSOFINE் ANALIZE்}

\section{S a n tra u k}

Nuo XX amžiaus vidurio, paūmejus visoms pasaulio šalims įtakos turinčioms aplinkos problemoms, aplinkosaugos verslo problema tampa vis aktualesnè. Vyriausybems igyvendinus aplinkosaugos politiką, JAV ir Vakarų Europoje buvo sukurta nauja gamybos pramoné, vadinamoji ekologinè pramonè. Ši ekologinè pramonè apima taršos kontrolès ir prevencijos įrangos kūrimą ir rinkodarą, aplinkos tyrimus, ekologinio stebėjimo ir aplinkos konsultavimo paslaugas (Krutyakova, 2001).

Aplinkosaugos verslo augimo tempas dabar yra itin didelis. Ypač strategiškai svarbios jo veiklos kryptys yra ekologiškai saugių alternatyvios energijos priemonių gamyba, geoterminès energijos plètra, aplinkai nekenksmingų gamybos metodų taikymas, priemonių, skirtų ịveikti aplinkos taršą dèl gamybos, igyvendinimas, išteklių išsaugojimo praktikos igyvendinimas, intensyvesnis bendradarbiavimas su novatoriškų mokslo ir technikos gaminių kūrejjais. Visa tai leis praktiškai naudoti tausojančias technologijas, įrangą, ekologiškas žaliavų rūšis, medžiagas ir degalus; aplinkos apsaugos priemonių ir labdaringos veiklos inicijavimas ir igyvendinimas, siekiant išspręsti neatidèliotinas aplinkos apsaugos problemas; ekologiškesni verslo santykiai su produktų vartotojais ir kryptingas dalyvavimas formuojant aktyvų aplinkos „lobizmą" valstybinèse institucijose.

Minètosios ekologinio verslumo veiklos kryptys yra nepaprastai svarbios šiuolaikinei Ukrainai, kuriai, kaip niekada anksčiau, reikalingi ypač siste- mingi valstybès ir aplinkos apsaugos verslo žingsniai.

Norint sèkmingai plètoti aplinkosauginị verslumą, būtina pagrịstai derinti ekonomines priemones (finansinę rinką, kreditus ir kt.), verslininku savanorišką veiklą ir ịstatymų reguliavimo bei kontrolès funkcijas (Krutyakova, 2001). Kiti svarbūs sèkmingo ekologinio verslo pletros veiksniai - tai visuomenès sąmoningumo aplinkos apsaugos atžvilgiu suaktyvinimas, ekonominių reiškinių (procesų) ir aplinkos būklès tarpusavio priklausomybès suvokimas, o tai tikrai yra gana nauja socialinès raidos paradigma.

Ekologinis verslas, kuris yra aukšto lygio ekonominès veiklos apraiška, daro teigiamą ịtaką naujos aplinkos koncepcijos formavimuisi. Tai atitinka naujojo amžiaus poreikius. Aplinkosaugos verslas prisideda prie ekologiško ekonomikos vystymosi, užtikrindamas ir tvarų šalies vystymąsi. Ekologinis verslas, kaip socialiai orientuoto verslumo veiklos kryptis, yra optimali šiuolaikinio verslumo ugdymo forma, nes tokia forma atitinka šių dienų reikalavimus. Pirma, jis padeda spręsti aplinkosaugos problemas; antra, jis revoliucionizuoja nusistovejusias (tradicines) verslo plettros formas, laikydamasis naujausio požiūrio ị aplinką; trečia, veikia kaip ekologiškai orientuotos ekonomikos (tiek vietinès, tiek globalios) plètros veiksnys.

Aplinkosaugos verslas, kaip verslininkystès veiklos forma, orientuotas tenkinti ne tik privačius, bet ir viešuosius ekonominius interesus bei visuomenès poreikius, bet ir yra aiškus moralès poveikio 
ekonomikai pasireiškimas; jo galimybès daryti ịtaką ir nulemti ekonominị žmogaus egzistavimą yra neabejotinos. Taigi ekologinis verslas yra perspektyvi socialiai orientuoto verslumo veiklos sritis ir komerciniu, ir moralès požiūriu; taip pat ir technokratiniu požiūriu dviem kryptimis: jo efektyvumo ir pelningumo požiūriu, tiek ir įtakos žmogaus humanistiniam tobulèjimui požiūriu, nes tai sukuria priemones ir sąlygas pagerinti žmogaus gyvenimo sąlygas, tobulèti jo kūrybiniam potencialui. Dèl šių priežasčių tai yra nauja socialinès pažangos ideologija. 